Article

\title{
Formulating Future Just Policies: Applying the Delhi Sustainable Development Law Principles
}

\author{
Maja Goepel \\ World Future Council, Rue Marie-Thérèse 21, 1000 Brussels, Belgium; \\ E-Mail: maja.goepel@worldfuturecouncil.org; Tel.: +32-485-203672; Fax: +32-2-2011780.
}

Received: 26 April 2010; in revised form: 5 May 2010 / Accepted: 28 May 2010 /

Published: 9 June 2010

\begin{abstract}
The nature of the concept of sustainability makes it difficult to coordinate and monitor the implementation of sustainable development in the formulation of effective policy. The International Law Association at its meeting in New Delhi in 2002 offered a set of seven Principles of International Law Relating to Sustainable Development as a definitive tool to inform the formulation of policy and potentially legal arrangements. This article describes a research project by the World Future Council that used these principles as the basis for a methodology to assess and evaluate how a range of policies might contribute to sustainable development in the interest of future generations. Three "best" policies on food security are evaluated and their common characteristics are identified. The article finally discusses how policy assessments based on principles accepted internationally might contribute to accelerated, effective and coherent implementation of sustainable development, even where the prevailing institutional approach treats ecological, social, economic and cultural issues as separate factors.
\end{abstract}

Keywords: New Delhi Declaration 2002; sustainable development principles; policy evaluation; food security; future generations

\section{Introduction: Formulating Policy for Sustainability}

"Sustainable development" seems to have gained a ubiquitous presence in policy debates. Yet the concept itself suffers from a certain degree of ambiguity. This may help to ensure its acceptability from many different local and global perspectives, from many cultures and regions. However, sustainable development's lack of conceptual clarity also creates diverse, and sometimes conflicting, 
interpretations of how the notion should be put into practice. This paper takes the perspective of the rights of future generations and conveys the results of a research project, conducted by the World Future Council, on the value of principled policy assessment for accelerated implementation of sustainable development solutions. The paper introduces the seven principles of International Law Relating to Sustainable Development adopted by the International Law Association (ILA), which serve as the basis for the Council's evaluative work, and discusses the core results of the research project before presenting the research methodology and process in more detail. It shows how a principled qualitative policy assessment serves as a sound basis for establishing a common yet flexible ground for discussing valid solutions to sustainability challenges. The piece describes how the use of a standardized questionnaire to determine how a particular law meets agreed principles encourages policy-makers, consultants, and legal experts to debate and refine their judgments. Such assessments can help to connect rather lofty principles with concrete practices and the final section of this paper discusses further the potential of this methodology, when it is applied to the process of developing new legal texts, and it outlines how the World Future Council promotes approved "best policies" as important solutions for our common future.

The World Future Council works to bring the interests of future generations to the centre of policy making [1]. The Council addresses pressing challenges to our common future by providing decision-makers with effective policy solutions. In-depth research underpins advocacy work for international agreements, regional policy frameworks and national lawmaking that support future justice, a concept integrating intragenerational equity with intergenerational equity. Future justice therefore starts today: the already prevalent destruction of nature is impacting the livelihoods of the poorest people and is likely to cause increased suffering and conflict in the future. Violence is destroying the social fabric of communities as well as the trust needed for peaceful human wellbeing. Without a quick shift to sustainable practices respectful of universal and inviolable dignity of all humans, the living conditions of future generations will only get worse-especially as our world population is still growing significantly.

From this perspective, a shift to sustainability needs diverse solutions that align with contextual conditions rather than the roll out of one big blueprint. What works well in one place may not work in another. Yet, a sufficient degree of coherence between different sustainability projects is desirable to avoid unintended side effects and consequences. Important contributions to coordinate efforts include the multifarious international treaties, national sustainable development strategies, and local Agenda 21 (sustainability) projects. Actual legal implementation, the development of single rules, however, is still happening in an institutional setting where economic, social, ecological and cultural issues are treated as separate units.

The research project of the World Future Council, with support of the Centre for International Sustainable Development Law (CISDL), seeks to develop a pragmatic methodology to assess single policies or laws in terms of their contribution to sustainable development. Unlike sustainability impact assessments based on quantitative data expressing anticipated results of a new law, this methodology is supposed to guide a qualitative holistic assessment of legal texts aimed at identifying and promoting best and therefore future just examples of sustainability law design. In line with the principles, this includes aspects relating to the governance processes in lawmaking, implementation, and development of existing laws, like participation, accountability, and evaluation of actual consequences. The overall 
goal of the project is to increase insight into common characteristics of policies and laws that - in their intent and effect - contribute to sustainable development. Identifying and understanding these characteristics means practices and customs of sustainability can be promoted in different cultures, societies and regions of the world. Various single initiatives may become more coherent and therefore effective, and yet there is contextual flexibility for each concrete policy design.

The Future Justice Commission [2], an explicitly transdisciplinary and multicultural body within the World Future Council, conducted the project. It chose to build upon the results of decade-long international legal consultations within the International Law Association and to work with the 2002 New Delhi Declaration of seven "Principles of International Law Relating to Sustainable Development". Upholding the notion that international agreements on sustainability are crucial frameworks for national policy-making, the principles were operationalized through the definition of a series of objective and inter-related questions that help scrutinize how an individual law or policy is contributing to sustainable development and where shortcomings may prevail. The resulting questionnaire was used for archival research as well as expert interviews with representatives from academia, civil society and politics, ensuring a standardized assessment.

The World Future Council intends to promote laws and policies of most significance for the protection of the interests of future generations and therefore searches for candidate regulation that implicitly or explicitly protects human rights in the long run through strong sustainability goals. The first research project on future just laws concentrated on policies on the national and sub-national level that successfully establish or support just and sustainable food systems, considering production and consumption from an integrated long-term perspective. In a first comparative testing of the methodology, the project team of the World Future Council analyzed five different laws that aimed at food security. While each of the laws was addressing "food security" in a different context, the team also identified commonalities in their design. This test has shown that the seven principles, even though originally defined for international law, have the potential to serve as an ideal norm that is universal and yet flexible enough to guide the drafting and amendment of laws and policies on any governance level. Empirically, the challenges addressed by the seven principles for international relations do exist on the intranational level as well.

\section{Results and Discussion: Using the Seven Principles of Sustainable Development Law [3]}

Applying law principles directly to individual laws in a qualitative evaluation represents a rather new approach, especially as global principles are used to analyze local and national legislation. The results of this research project show that such a principled methodology serves to identify policies and laws that show a truly integrated approach to sustainability, foster respectful cooperation, equitable participation, and fair sharing of resources and benefits of economic, scientific and technological progress. This is particularly true because the ILA Principles are consistent with the 2002 Johannesburg Plan of Implementation of the World Summit on Sustainable Development. The Principles help to focus decision-makers' attention on expected outcomes for all those elements, as well as on governance structures and processes conducive to their effective implementation. Using these Principles for single policy assessment on any governance level may also ensure coherence between diverse legislative developments. After a brief background on the New Delhi Declaration and 
the importance of food security for sustainable development, the methodology and results of the analysis are presented.

The New Delhi Declaration provides the most current benchmark of important principles of international law on sustainable development [4-6]. It was based on a comprehensive and balanced decade of study and analysis by the International Law Association's (ILA) Committee on the Legal Aspects of Sustainable Development, and it has a high degree of normative clarity. In the last three decades, several global-scale processes have been undertaken to develop principles of international law on sustainable development. These processes (and debates) have been intense, engaging experts and grassroots leaders from all corners of the world, and building on decades of careful, rigorous analysis. The most important undertakings ran parallel to several global policy making processes. The most important of these began with the process of elaborating the 1972 Declaration of the United Nations Conference on the Human Environment in Stockholm [7]. That was followed by the 1987 Report of the Legal Experts Group on Principles of International Law for the Protection of the Environment and Sustainable Development, which accompanied the report of the World Commission on Environment and Development (or Brundtland Commission), entitled Our Common Future [8]. The Legal Annex to Our Common Future [8] was the outcome of years of high level and grassroots global consultations by the World Commission on Environment and Development. It built on the Stockholm Declaration but included a considered legal analysis, commentary and a clear normative proposal for each of its proposed principles. Our Common Future proposed the adoption of 22 legal principles, divided into four groups, meant to address the challenges identified in the report and to guide future law-making in the areas of environmental protection and sustainable development.

The United Nations Conference on Environment and Development (or Earth Summit) in 1992 produced a set of principles for sustainable development, called the 1992 Rio Declaration, and a plan for global sustainability, called Agenda 21 [9,10]. The 1992 Rio Declaration was clearly influenced by the principles recommended in the Brundtland Report; many of the Brundtland principles are similar to the twenty-seven principles contained in the Rio Declaration. The Rio Declaration is widely accepted as "soft law" [5,11-13]—not legally binding but nonetheless relevant to the development of "hard" international law for sustainable development. The Rio Declaration principles are reaffirmed and specifically mentioned throughout Agenda 21.

The Rio Declaration was followed by the Report of the Expert Group Meeting on Identification of Principles of International Law for Sustainable Development, which was commissioned by the UN Division for Sustainable Development in accordance with a request by States at the second session of the UN Commission on Sustainable Development in 1994. This report, which was released in September 1995 [14,15], identifies nineteen principles and concepts of international law for sustainable development based on the Rio Declaration, Agenda 21, international treaties and other legal instruments.

Following up on the recommendations of the report, the International Law Association's (ILA) Committee on the Legal Aspects of Sustainable Development released its New Delhi ILA Declaration on Principles of International Law relating to Sustainable Development as a Resolution of the 70th Conference of the International Law Association in New Delhi, India, 2-6 April 2002 [16,17]. The Declaration notes that "sustainable development is now widely accepted as a global objective and that the concept has been amply recognized in various international and national legal instruments, 
including treaty law and jurisprudence at international and national levels..." [17]. It outlines seven principles of international law on sustainable development. These principles, which were already in the Brundtland Report and the 1992 Rio Declaration, are the central principles of most international treaties related to sustainable development. The Johannesburg Plan of Implementation [18], which was agreed to at the World Summit on Sustainable Development later in 2002, recognized and reaffirmed these principles. (Detailed analysis of the history of sustainability principles is beyond the scope of this paper and can be found elsewhere $[11,12,19])$.

\subsection{Turning Principles into an Assessment Tool for Laws Protecting Future Generations}

The seven principles in the ILA are:

1. The duty of States to ensure sustainable use of natural resources;

2. The principle of equity and the eradication of poverty;

3. The principle of the precautionary approach to human health, natural resources and ecosystems;

4. The principle of public participation and access to information and justice;

5. The principle of good governance;

6. The principle of common but differentiated obligations;

7. The principle of integration and interrelationship, in particular in relation to human rights and social, economic and environmental objectives [20].

These norms are not exhaustive and several are not yet recognized as binding rules of customary international law. In some cases, they might never be. However, they are increasingly made operational in binding international treaties, forming part of international law and policy in the field of sustainable development, providing normative context for best policies and laws in the field, as well as in Local Agenda 21 initiatives and national sustainable development strategies. Nico Schrivjer, Chair of the ILA Committee on International Law on Sustainable Development, presented the Principles of the New Delhi Declaration as a "first blueprint for the emerging field of sustainable development law and policy", as well as a "first crucial and definitive tool" for professionals dealing with policy-making and evaluation [20]. At the subsequent World Summit on Sustainable Development, Heads of State agreed to "promote coherent and coordinated approaches to institutional frameworks for sustainable development at all national levels, including, as appropriate the establishment or strengthening of existing authorities and mechanisms necessary for policy-making, coordination and implementation and enforcement of laws" [21]. At the World Summit, the Netherlands identified the New Delhi declaration as responsive to that agreement.

How exactly these benchmarks are met by each assessed policy will of course differ, depending on the legal context that it has been developed for and reflective of each societies' culture, practices and environmental or economic challenges. The assumption is that a principled assessment of individual laws, regardless of the governance level, will ensure a holistic, qualitative debate on how certain elements of a policy are foreseen to support sustainability. This assessment encourages an integrated perspective on the policy goals that seems particularly relevant in national lawmaking, where environmental, social, economic and cultural challenges are addressed through separate, sometimes even competing departments. Also, all of the challenges for sustainable solutions that are addressed by 
the principles for international relations find their counterpart on the intranational level as well, where different stakeholder, communities and regions seek to find consensus on integrated equitable solutions that also safeguard opportunities for future generations. Even the principle of common but differentiated obligations, originating from the notion of common heritage of humankind, provides good guidance for national or local relationships where higher wealth usually correlates with higher resource consumption patterns and provides for more economic capacity to carry costs related to environmental protection. Also, paragraph 81 in the Johannesburg Plan of Implementation makes explicit reference to the significance of this principle in Agenda 21, suggesting that it not only applies to environmental protection, but also to social development goals such as poverty eradication.

To actually turn the "definitive tool" into a mechanism for policy-making, coordination and implementation, the World Future Council Commission on Future Justice developed a standardized questionnaire on how laws under scrutiny meet the principles. The Council's work shows that as criteria for the identification, development or amendment of laws for sustainable development, the universal principles provide a useful set of benchmarks that, ideally, establish common design features of future just policies for sustainability.

For the development of such a "best policy" assessment methodology, the Future Justice Commission [22] met in April 2008 in Santa Barbara to discuss the use of the Delhi Principles in the selection of "best policies" for future generations. Slight changes in the principle on "good governance" were made, as some experts felt the clear association with World Bank standards would evoke mistrust or even rejection in some countries and by some groups. Instead, a focus on Human Security (freedom from fear and freedom from want) was made explicit in the governance principle, building on the definition of the Commission on Human Security led by Amartya Sen: "protect the vital core of all human lives in ways that enhance human freedoms and human fulfillment" [23].

With the adoption of the slightly modified principles, the Commission also agreed on a series of objective and inter-related questions that could guide the assessment of individual laws with the goal of identifying leading examples in support of sustainability. The result is a practical questionnaire methodology (presented in the empirical section below) that helps to clarify how a law or policy embodies sustainable development principles and where blind spots may lie. This questionnaire is not restricted to actual mentioning of the principles or related concepts in the legal text, but rather seeks to evaluate the holistic reasoning behind and composite effect of the regulation or regulatory framework assessed. Thus, the "principled criteria" are not meant to provide a "check-list" by which to judge policies so that "the best become the enemy of the good". Rather, they seek to help policy-makers, civil society and others to evaluate or draft new laws and policies carefully, and to ensure they have taken into account important universal principles. This way, international consensus can serve as a reference framework in the assessment of diverse national developments, supporting policy coherence and potentially serving to overcome existing and very legitimate regional, cultural and technological differences. The identified characteristics and concrete examples of "best policies" can be shared successfully and appropriately, taking into account surrounding legislation and policy contexts which contributed to their success. In essence, this standard seeks to help identify the actions, practices and policies whose adoption could radically enhance the prospects of sustainability of life on our planet, in order to promote the integrity of future generations. Thus, while not all questions on the principles apply to all laws and hardly any law will address all principles explicitly, the methodology allows for a 
structured assessment of concrete solutions regarding their holistic approach. The goal is not necessarily a ranking, but a standardized selection of leading examples of sustainability policy implementation and the identification of core characteristics that make them successful in intent and effect.

\subsection{Food Security as a Fundamental Challenge for Sustainability}

Over 1 billion people are currently living under violation of their most fundamental human right, the right to food. Despite increased efforts on the international level to agree an agenda on food security, an unprecedented number of humans still go hungry, and 30,000 children die every day. If humans do not eat, they do not live. Lack of food weakens human health and potential, causes people to lack the strength to be productive, and creates and perpetuates misery, suffering and inequalities. Hungry people also cannot afford to pay attention to the ecological impact of their hunting, planting or harvesting. Securing sufficient and good food in a sustainable manner may be the most fundamental challenge to a peaceful future. Unsurprisingly, eradication of "extreme poverty and hunger" became Millennium Development Goal Number 1 in 2000 [24].

Article 25 of the Universal Declaration of Human Rights subsumes the right to food under the right to "a standard of living adequate for the health and wellbeing of himself and of his family" [25]. The International Covenant on Economic, Social and Cultural Rights recognizes both the "right to an adequate standard of living, including adequate food" and the "fundamental right to be free from hunger" [26]. The 1996 Rome Declaration on World Food Security hosted by the United Nations Food and Agriculture Organization states that food security "exists when all people, at all times, have physical and economic access to sufficient, safe and nutritious food to meet their dietary needs and food preferences for an active and healthy lifestyle. The four pillars of food security are availability, access, utilization and stability. The nutritional dimension is integral to the concept of food security" [27]. This definition does not necessarily respect other human rights and freedoms, though, but could indeed be fulfilled through dictatorial feeding-programs. Thus, scholars, human rights advocacy organizations and small farming associations have promoted the concept of "food sovereignty" instead, focusing on democracy and participation in the production of food as well.

The recent declaration of the Civil Society Organizations' Forum in parallel to the international World Summit on Food Security from November 13-17 2009 in Rome asserts that "Food sovereignty entails transforming the current food system to ensure that those who produce food have equitable access to, and control over, land, water, seeds, fisheries and agricultural biodiversity. All people have a right and responsibility to participate in deciding how food is produced and distributed. Governments must respect, protect and fulfill the right to food as the right to adequate, available, accessible, culturally acceptable and nutritious food" [28]. The concept of food sovereignty resembles the multifunctional approach of food security as defined by the Food and Agriculture Organization (FAO) where the importance of local, participatory agriculture forms an integral part [29].

\subsection{Presenting Three "Best Policies" for Food Security}

For this first round of principled policy assessment, the World Future Council issued a nomination call to its networks and also conducted a search for candidate laws itself. As a result, three policies 
were rated as (on balance) meeting the seven principles in a holistic manner, explicitly in the formulation of their goals and also in their actual effect. All pursue a human rights approach to food. This research allowed for the identification of similar characteristics that seem to be fundamental for successful sustainability solutions that should be validated through further assessments.

Under the broad rubric of food policies, there are various interpretations of how problems of food insecurity should be addressed, depending on contextual challenges as well as cultural differences. This was reflected in the nominations: the proposals dealt with various issues at different stages in the food security chain-including agricultural independence from world market prices, local production and consumption circuits, sufficient production without pesticides and within cities, healthy feeding programs, the protection of indigenous breeds for secured biodiversity, and resilience of production. Five policies targeting very different challenges to food security and from four different continents were chosen for a principled screening, ranging from the national to the local level of governance. The difference of the respective objectives within the broader issue of food security provided a good test for the application of universal principles in different legal, social and cultural contexts, as well as to diverse local challenges of the globally agreed goals. The five laws assessed through structured interviews were:

1. Region of Tuscany, Protection and Promotion of the Heritage of Local Breeds and Plant Varieties, Italy [30]

2. Urban Agriculture, Cuba [31]

3. City of Belo Horizonte Food Security Program, Brazil [32]

4. Kerala State Organic Farming Strategy, India [33]

5. Food Security Strategy, Ethiopia [34]

After a first round of interviews, the World Future Council selected three policies for public promotion as very successful examples. The other two policies are not actively promoted for different reasons. The policy in Kerala, even though an impressive example of an integrated approach to food security, has only been in place since 2008 - not long enough for its effects to be evaluated. The Ethiopian policy, in contrast, failed in its educational outreach to small-scale farmers because, as became clear in interviewing process, language and media access barriers were underestimated and food insecurity had increased [35]. A description of the three exemplary policies for food security is presented below, followed by a discussion of the commonalities between the three laws that were identified in the analysis and that seem to be important criteria for their success. The questionnaire used in this research project - which is based on the principles contained in the New Delhi Declaration, is set out in the Appendix, along with the methodology and standards used to evaluate the results of the archival research and interviews. Out of the three short listed candidates, the City of Belo Horizonte, Brazil, had the most comprehensive and effective policy, explicitly pursuing a human rights based approach and integrating economic, social, ecological and cultural components in a trans-sectoral implementation strategy. The following paragraphs provide summaries of the laws assessed with brief reference to the principles. 
2.3.1. Region of Tuscany, Protection and Promotion of the Heritage of Local Breeds and Varieties of Agricultural, Zootechnical and Forestry Interest

Tuscany's Law is a good example of how local and regional governments can take responsible and concerted action to protect seed diversity and allow small farmers to have more control in the conservation of particular "noncommercial" seeds and varieties. The fundamental idea behind Regional Law No. 64/2004 on the protection and promotion of the heritage of local breeds is the right to use collective heritage. Seed biodiversity is seen as necessary for the survival of species and the safeguarding of rural heritage. This law establishes a regional register of conservation varieties, with the aim of enabling commercialisation of such varieties, once the appropriate quantitative restrictions are made. The law protects seed varieties as "natural insurance" for the future of society and protects the rights of farmers as legitimate trustees of this resource. This law's forerunner, regional Law No. 50/1997 "Protection of the autochthonous genetic resources", had principally scientific aims in recording local breeds and varieties. Regional Law No. 64/2004 integrated the scientific aims of the previous law with economic and social goals. Building onto the listing of local breeds and varieties, so that their characteristics and also samples would be recorded, the expanded law is geared toward the actual use and cultivation of diversified crops as a common heritage. The law makes it possible to exchange limited quantities of propagation material and to market limited quantities of seeds not currently commercialized. In this outset the law meets several of the sustainable law principles, from the duty to protect the environment over equity and poverty eradication, precaution and the integration of economic, development and environmental goals.

Operationally, the law first requires the identification of the resource (characterization, on site-survey, assessment), then conservation (on farm and ex-situ) and lastly the enhancement or promotion of the breeds and the guarantee of collective use of local breeds (local projects, branding, information). Measures include the establishment of germplasm banks; the nomination of "custodian" farmers; the development of networks between growers, custodians and regional germ banks; the promotion of a regional brand for marketing; community fora for engagement; and the forging of research and development links. Other provisions encourage the registration of native varieties and species in biodiversity conservation catalogues as well as the use of these varieties and species in the agricultural sector. The law is premised on the view that seed biodiversity is necessary for the survival of species, for safeguarding rural heritage and for building resilience of farming. The law also promotes and protects local breeds and varieties and their cycles of reproduction and ensures that farmers have access to sharing local seeds and knowledge, giving value to local organic agriculture as a model for economically, culturally and environmentally sound livelihoods. The law involves the Tuscan Regional Government, the Ministry for Agriculture, the ARSIA (Regional agency for development and innovation the farming and forestry sector), nongovernmental organizations, "custodian" farmers, other farmers, and local community citizens. These provisions and processes cater to the principles of transparency, access to information, participation, governance, human security, and to a certain degree common but differentiated obligations through the aims to prevent seeds from becoming patented, guaranteeing access to all humans that want to grow food. Also, underpinning the law is the notion that the varieties and knowledge of seeds in regional areas are a collective right. 
Tuscany has been at the forefront in denouncing the use of genetically modified organisms (GMOs), in promoting organic farming and in safeguarding the genetic heritage of the region. Civil society and government partnerships in Tuscany were instrumental in the construction of a network of regional and local governments, public and private entities and movements on sustainable, biodiverse and GMO free food systems. This resulted in the creation of the International Commission on the Future of Food and Agriculture in 2003, a group which seeks to shape a new future of food in which small farmers' livelihoods are economically and culturally vibrant and ecologically resilient.

As a result of the law, hundreds of breeds have been registered on the regional register and are being protected both in- and $e x$-situ, proving its effectiveness. Also, many other regional governments in Italy have adopted a similar law, whereas an upscaling to the national level currently seems unlikely, mainly because of potential conflict with other intellectual property interests and European regulation. In terms of transferability to other contexts, the idea of collectivity is not known in every country. However, interviewed experts noted that the collective rights seen in Italy also exist in Spain. There are some remnants of this idea in France, Switzerland, Belgium and the Netherlands. In many other areas, such as Africa, the notion of collective rights still exists. Thus, this idea could likely be transferred to an Asian and African context. Small farmers are marginalised in many areas by the rules of conventional food systems and sustainability strategies often declare this to be one of the fundamental shortcomings in current development patterns. Collective rights provide a tool of empowerment that could be at the core of new solutions. Public engagement and strong political will would nonetheless be needed to go against modern "accepted norms" and the direction that the European Union or international agreements on intellectual property rights foresee.

\subsubsection{Cuban Urban Agriculture}

Since the early 1990s, an urban agriculture movement has swept through Cuba, reaching rural areas as well. Originally it resulted from pure necessity when the fall of the Soviet Union meant the loss of more than 50 percent of oil imports, much of Cuba's food, and 85 percent of its trade economy. In response to severe shortages in food, pesticides and petroleum, people began cultivating vegetables wherever they could, including lots in downtown Havana and other urban spaces throughout the island. The urban agriculture movement was first led by the people but policy makers, after initial recalcitrance, realized the potential of the movement and invested in its development. There had been some research into urban agriculture prior to the crisis, but by the Ministry of Defence, which was making provision for a potential embargo, rather than the Ministry for Agriculture.

The government's first and most important step was to officially license unused space to be utilized for cultivation. That step was taken with the adoption of Law No. 142 of 1994, relating to usufruct ownership of land. The law makes it relatively easy for individuals or groups of people to gain access and usufruct ownership of land that is not productive, clearly meeting the principles on poverty eradication and also common but differentiated obligations and integration when the production of food overrules other ownership claims and construction plans. Since then, Cuba has developed a comprehensive and detailed policy framework for urban agriculture. This framework of policies has evolved with the challenges it has faced. Existing rules and regulations governing the agriculture/livestock sector have been adapted and adjusted, and others were adopted specifically for 
the purpose of urban agriculture. These other laws support public research and development of highly diversified, organic production technologies and fertilizers; the provision of high quality seed and technical advice, information and education services; and the encouragement of on-site vending were added over the years. As a result, organic urban farming makes very efficient use of whatever plot of land is available, is a source of employment for many persons, and provides fresh produce with zero transportation costs or emissions.

The main purpose of this framework is to encourage production and consumption of nutritious food, to increase the variety of nutritious food available to people, to supplement the basic rations guaranteed for every citizen, and to encourage community participation. The idea is produce food locally and to distribute it as close to the source as possible. Every member of the population - not just those who are nutrient deficient or vulnerable to food shortages - is encouraged to become involved in urban agriculture, whether through production, consumption or education. The program particularly addresses the needs of children, the youth, workers and the elderly.

This framework is continually developed and includes very detailed expertise and support schemes. The state provides infrastructure and low-interest loans. Many different types of production are carried out ranging from patio and terrace planting to intensive gardens to organoponicos (walled beds) to small, diversified farms. Most of these are registered and monitored by the municipal department. Extension agents are employed to assist and inform gardeners about technology, biofertilizers, composting, and recycling. The government also supports research and technology development. The state encourages on-site sale and also subsidizes rents for farmers markets in central locations.

The Ministry of Agriculture set up the National Urban Agriculture Group (Grupa Nacional de Agricultura Urbana), which also has provincial and municipal groups, to promote urban agriculture. Administration is handled by the Services office (Granjas Urbanas), which has responsibility for training and service provision. State linked enterprises (Empresa) are involved in marketing and sales, while community consultative groups are set up in each area (Consejo Popular) to enable participation and representation of citizens. In its evolving intent and effect the law therefore also meets the duty to protect the environment, precaution, participation and access to information as well as governance and human security in the sense that individuals are empowered to cater for themselves if necessary.

Urban agriculture has had a significant impact on nutrition and food security by increasing access to fresh fruit and vegetables. It has also increased the use of organic and sustainable farming and composting methods, reduced food prices, provided employment, and led to greater education and community participation. Informants speak very highly of the government's policy development in this area and are especially impressed with how comprehensive and far reaching it is. The number of jobs created, range and output of produce cultivated, and the number and diversity of projects developed are all very high. No other country in the world has such a comprehensive and regulated system for urban agriculture with such highly defined objectives, detailed projected outputs, and which integrate environmental, social and economic objectives. Critics note that food is still sold on the black market or is only available with foreign currency.

The Cuban urban agriculture policy framework is an example of an extremely regulated system. Some have also said that such a system could not work in other countries where greater availability of oil and gas make it less obviously necessary. Others, however, say that elements of the policy framework could be easily replicated in other countries and would be a potential answer to many 
problems in modern cities. Organic, locally produced and distributed food with negligible transportation costs, and the transformation of abandoned spaces into "green" and productive areas, could be attractive in many other contexts, civil society movements are starting across the globe.

\subsubsection{Belo Horizonte, Food Security Program}

The Belo Horizonte, Brazil, food security program was first implemented in 1993 and has since become increasingly comprehensive. In 2004 the program became a role model for the national strategy to fight hunger of the new Lula da Silva government. In 2006 Belo Horizonte issued a law securing the permanence of the more comprehensive policy.

In 1993, a time of social mobilization against hunger and misery, the Partido dos Trabalhadores (Workers' Party) was elected in Belo Horizonte. Belo Horizonte's approximately two million citizens were experiencing food insecurity because of high prices, uneven distribution of food outlets throughout the 350 square-kilometre city, and various problems in urban infrastructure. The city's food security law, Municipal Law No. 6,352, 15/07/1993, which was enacted shortly thereafter, sets out a policy framework for food security and created the Municipal Secretariat of Food Supply (SMAB), the body responsible for the development of its programs. The goal of the law was to improve both food availability (sustainable production) and food accessibility (affordable prices, local control). Since then there has been an evolution, whereby existing rules and regulations have been adapted and adjusted.

The municipal government recognizes citizens' rights to "adequate quantity and quality of food" and a "duty of governments to guarantee this right". It therefore manages the provision and distribution of food to groups and parts of the city where this right is threatened. Every member of the population who may be food insecure, but also those who are not food insecure, is deemed to have the right of access to and availability of nutritious and quality food. The vulnerable are guaranteed highly nutritious food (for example in schools and hospitals), while the marginalized are given access to low cost produce directly in their areas of residence. The city invests in community food sovereignty programs that address health, social equality, job creation, diversified agriculture, and the encouragement of local food production. The outset of this policy clearly meets the principles on poverty eradication and equity and precaution towards the health of the population and the production of food.

Although the recognition of the right to food security is an important element, the policy goes much further and promises the delivery of the service by following a systemic approach that includes food producers, distributors, and consumers. According to interviewed experts, the means and methods of delivery are far superior to any other system. The law applies to every stage of the food chain, including research and development of (increasingly organic and also urban) farming technology, credits for family farmers and support of farmers markets, waste disposal, decentralized distribution, feeding and health education programs, operation of popular restaurants and, recently, financial assistance. The program also includes a formal evaluation process. In these provisions the principles of governance and human security, participation and access to information, and the protection of natural resources find reflection.

A wide range of projects have been developed to help large groups of people. The idea of "food with dignity" permeates the whole program. Examples of these projects are a school meals program, 
the use of popular restaurants to provide subsidized food, local markets for food, and a "direct from the countryside" scheme. Community participation and engagement, workshops, and incentives for involvement are all supported and managed by an efficient, flexible and decentralized administration. The federal government provides some of the funding, but due to Brazil's system of decentralization, most of the power is in the hands of the municipal government, particularly the SMAB. Separate departments within the SMAB are responsible for prevention and reduction of malnutrition, food distribution and availability, and food production and facilitation. Under a 1994 municipal law, civil society organisations, farmers and citizens all play an important role in the scheme. Here, the notions of integration, and to some extent common but differentiated obligations, come into play: supermarkets donate leftover food to the program and small farmers participating in the scheme use unproductive private property around the city. Yet, the question of land ownership remains a source of conflict and the government has not found a satisfying solution until today.

With this policy framework, Belo Horizonte has succeeded in mainstreaming food security issues into public policy and provides a model that has "unpacked" poverty. What has emerged is a highly effective but low cost scheme using less than $2 \%$ of the city's annual budget (approx. US\$9 million). There has been greater access to and availability of nutritious and fresh produce, a decrease in child mortality, a reduction in childhood and adult malnutrition, increased and stable income for farmers in the surrounding areas, and an increase in local and organic food production and consumption. It is a labor intensive project, which requires much organization and commitment. Some say that it would not work in other cities, as its success may be a result of individual commitment and the political culture in Belo Horizonte. Transferred to a larger scale, it might be opposed by agro-industrial companies, food manufacturers, and retailers if they perceived such a program as economically threatening. Still, its success and durability make it a highly attractive model that outlines a solution particular for contexts in which sufficient food is technically available but not accessible for the poor and marginalized groups of the population.

\subsection{Results and Commonalities of the Evaluated "Best Policies"}

These three policies incorporate a human rights approach to food. They all view people as citizens with skills to participate in ensuring human rights rather than as market participants or consumers. In the case of food security this means making available resources accessible for as many citizens as possible. Depending on the particular challenges, the type of resource was different: The Belo Horizonte Food Security Program ensures access to food through free meals and supports local production and distribution. The Cuba Urban Agriculture Policy ensures access to land necessary to grow enough food and promotes local production and distribution. The Tuscany Plant Heritage Policy ensures access to seeds, enabling farmers to save, protect and use them, which promotes local production and distribution and prevents exclusion because of private commercial patenting.

Interviews have underscored the fact that the encouragement of local food production was the most important policy program from a medium to long-term perspective. While emergency help is necessary in acute moments of crisis, sovereignty in the control over the whole food chain addresses the goals of food security and sustainable development through four important, interrelated effects: 
- Poverty reduction - incomes of often poor small farmers close to the city rise while more people can buy the food they need.

- Rural sustainability - farmers can stay on their land instead of migrating to the overcrowded city with high unemployment and poverty rates.

- Healthy nutrition - family agriculture increases the availability of fresh and health-promoting food for all citizens not produced by big farms aimed at export scales.

- Price stability - increased local production reduces disturbances through volatile world market prices impacting imported goods.

The assessment of future just policies not only looks at the intent of a law, but also at its actual effects, addressing the processes of governance and determination to develop upon evaluation of the impacts. The assessment reports showed that the most important success factors for effective policy implementation have been the following:

- Transparent public communication and education on the goals and strategies.

- Organized citizen participation and multiple public-private partnerships.

- Clear organization with the bundling of tasks under one distinct agency with its own budget and continuously adapting the program through evaluation.

- Addressing food security in its entire chain of production and consumption.

- Securing the right to food through legislation resilient to government changes.

The interesting result here is that the empirical findings about most effective policies in practice do support the universal principles addressing governance processes (principles four to seven). The first three principles find reflection in the actual and explicit policy goals, responding to scientific evidence, treaty obligations, higher moral standards, or constitutional rights (the duty to ensure sustainable use of resources, equity and the eradication of poverty, the precautionary principle).

One additional important aspect for successful policy implementation is of course dedicated commitment and smart leadership in order to organize different sectors and one-issue bodies behind one integrated program. This became very clear when meeting with the 1993 Mayor of Belo Horizonte, Patrus Ananias (now national Minister for Social Affairs and the Fight against Hunger) and his assistant, Adriana Aranha. With the establishment of the Belo Horizonte Secretariat for Food Policy and Supply (SMAAB), Ananias ensured that tackling hunger was no longer a matter of "emergency help" Instead, access to healthy food for all became a measure of social justice that was integrated into policy making across departments, where root causes and structural issues could be considered. As Aranha summarizes: "The subject of food security is broad. I believe there is a responsibility that has to be divided. The market has responsibility, the state has responsibility, and society has responsibility. It reaches from production to consumption, encompasses issues of sustainability and the environment. It does no good if people are producing food in a way that compromises future generations" [36].

All three policies fare high in meeting the seven principles adopted by the International Law Association. They show a truly integrated approach to sustainability and foster respectful cooperation, equitable participation, and fair sharing of resources as well as of the benefits of economic, scientific and technological progress. 


\section{Principled Adaptive Governance as Key for Future Just Law Making}

This "first blueprint for the emerging field of sustainable development law and policy" (Nico Schrivjer) has proven to be a helpful tool in identifying and evaluating common features of effective solutions for sustainability and the interests of future generations. It is a principled and qualitative benchmarking method that can help to guide policy in a flexible but coherent manner, so that unintended consequences and side effects are avoided while concrete solutions continue to reflect the diversity of circumstances on this planet. In recent global policy-making processes, especially through the summits in Rio de Janeiro and in Johannesburg, states have not agreed on one definition for sustainable development. Rather, they have focused on developing greater global consensus on how to achieve sustainability. The world's thousands of societies have diverse traditions and cultures, livelihoods, climates and living conditions. Economists, scientists and development scholars have only begun work on the necessary indicators and instruments which might help to answer these questions in varying conditions and contexts. International development objectives continue to evolve, as does our understanding of sustainability for different sectors, societies and conditions.

It seems highly unlikely that there will be one globally recognized and permanent definition of "sustainable development" Use of a principled and qualitative methodology serves to establish a common ground for discussion of what is considered a valid solution to meet sustainability challenges. The results will by definition be integrated assessments that take economic, financial, social and environmental considerations into consideration, key for sustainable development on any level of governance from the global to the local. Meanwhile, focusing answers on the seven principles for sustainable development law will ensure that policy judgments will expose differences in worldviews and convictions about how the outlined criteria can be met. This approach can help overcome roadblocks in the policy making process and inform the definition or reassessment of the quantitative indicators chosen to monitor the success of the policy: some may be convinced that growth in Gross Domestic Product (GDP) is the most important goal and indicator to ensure poverty eradication, whereas other viewpoints will measure the amount of households capable to live in subsistence communities. Following the standardized questionnaire makes worldviews and differences in basic premises visible in an objective, differentiated and discursive manner. The answers provide a good basis for constructive engagement on differences in ideological positions, cultural precepts and knowledge levels that are fundamentally important for successful policy implementation, but very often overlooked when pushing for "good governance". From the perspective of future justice and the interests of future generations, this is of fundamental importance: many of the premises, concepts and also institutional solutions forming our modern societies are very focused on the present or short-term and individuals rather than communities. Also, nature is often viewed and treated as a mere resource for human production and the view of it being an intricate web of life that is common heritage to be safeguarded for succeeding generations has been lost. Given the current multiple ecological, economic and social crises, a reassessment of fundamental beliefs seems to be unavoidable if the rights of future generations are taken serious.

This methodology may therefore serve not only as the basis for external evaluation by organizations such as the World Future Council, that want to ignite such deeper reassessments and promote best examples of future just laws, but could also be a powerful tool in debates among policy-makers during 
the writing of a legal text. Moreover, the methodology seems to be applicable in times and contexts where institution-building and diversified law-making is less developed. High levels of corruption often lead to a significant degree of mistrust in public institutions that will hinder participatory processes or voluntary compliance with rules. Transparent policy assessment may become a trust-creating measure, and frequent evaluations could inform the monitoring of officially agreed amendments. Using the seven principles when assessing one individual law helps to ensure the holistic view necessary to develop truly integrated solutions. The World Future Council will not only continue its annual Future Policy Award to champion best policies for sustainability but it will also develop a Toolkit to include evaluation scales, more background information, and empirical examples on integrated sustainability assessment and potential best governance.

One forthcoming challenge involves applying the same methodology in the assessment of several laws of one nation or region. This holds the potential to increase policy coherence, avoiding the risk that the impact of one policy is detrimental to the goal of another one. Assessing each law in terms of the final goals of sustainability will also help to (re-)balance the three pillars of sustainability. Currently, the economic growth paradigm often subjugates the social, ecological and cultural aspects of sustainability. The example of hunger in a world of plenty provides a perfect example for the resulting distortions. There is no shortage of food. Agricultural production per person has increased by $20 \%$ worldwide since 1980 [37]. Hunger is not a result of poor economic growth. India's progress in reducing hunger came to a halt during the booming 1990s [38] and half of its children still suffer from malnutrition [39]. It's not necessarily a consequence of fast population growth. In China each couple can only have one child, yet the number of hungry people rose in the boom periods 1995-1997 and 2002-2004 [37]. It seems to be the result of market structures that are competitive, profit seeking and speculative, creating price structures that exclude the poor from access to healthy food and hinder investments into small-scale agriculture. World food prices roughly doubled between 2006 and 2009, yet the most significant jump was in a single year, between April 2007 and April 2008, when prices rose by $85 \%$ as speculators re-oriented their portfolios toward food commodities [40]. In many developing countries the agricultural sector was more productive 50 years ago than it is today. During that period, between 1980 and 2002, official development aid for small-scale agriculture was cut by $85 \%$ [40]. Our highly decentralized, convenience oriented, industrial agricultural system eats up to 10 times the amount of calories that it delivers for the consumer [41]. Had each of the political decisions leading to this situation been assessed concerning their impact on the ILA principles, we might have prevented the subjugation of social, environmental and cultural political goals under the economic growth goal. Also, transparency, participation and access to redress may have created the necessary negative feedback loops to keep systems in a more sustainable dynamic equilibrium.

\section{Conclusions}

The research project described in this article demonstrates that the New Delhi Declaration Principles can inform a qualitative tool allowing civil society, experts, and policy-makers to assess and encourage laws and policies that make strong contributions to sustainability and therefore protect the interests of future generations. The approach that was taken helps to tease out the most important and fundamental elements of such laws and policies, so that they can be understood and promoted in 
different cultures, societies and regions of the world. It can also guide policy-making for sustainability when law and policy-makers use the methodology to consider additional elements for a new law or policy. Also, a structured and objective reassessment of fundamental beliefs about causal effects in complex systems and preconditions of resilient relationships lies at the core of designing solutions that will take us from the current crises towards solutions safe in the long term. Thus, while the questionnaire was designed to provide a qualitative evaluation of a law or policy within its own social and legal context after several years of experience and effects, it can also function as a source of evaluation - and inspiration — for new laws and policies affecting future generations. After all, policies that inspire are those that bring positive change.

One of the most important lessons learned is that a qualitative assessment highlights the interplay between a legal text, its interpretation, and its actual effect. Successful policy-making for sustainable development will entail significant changes of the currently implemented development model. What is needed is an iterative, adaptive process and a continued quality assessment to ensure it is on the right track. The evaluation methodology described in this article provides a solid basis for such an assessment.

\section{Acknowledgements}

This article presents the results of an exciting group project that involved many people dedicating volunteer time to it. While the legal expertise of CISDL was of course invaluable, the commitment of Marie-Claire Cordonier Segger went much beyond the research papers that the Centre was contracted for. As a Councilor of the WFC she was permanently available for consultation on the process of operationalization and played a significant role in bringing the Future Justice Commission behind the project. The Commission and Jakob von Uexkull, Founder of the World Future Council, provided me with an amazing scope of freedom to implement the agreed research and awarding process of the best food policy. I thank them for their trust. Yet, the project would have never been possible, had it not been for Niamh McMahon. Coming to the World Future Council for 5 months only, she familiarized herself quickly with the framework and conducted all the field research independently, becoming friends with experts in many countries, including the Ethiopian Minister for Agriculture and Rural Development. I thank the Selection Committee for the Future Policy Award for their engagement and feedback on research output and presentation and look forward to its further refinement. The reflections on the value and potential of such principled policy assessment, however, are mine alone and may differ from those of other persons having followed the research project. Finally, Alice Vincent's editing and formatting support allowed for an academic piece to develop in a context of hectic policy advocacy.

\section{References and Notes}

1. For more information on the organization, its members and programs, please consult: http://www.worldfuturecouncil.org. 
2. The commission is comprised of World Future Councilors and commissions research with the CISDL. It includes Hr. Arthur Robinson (former President Trinidad \& Tobago), C.G. Judge Weeramantry (former Vice-President, Court of Justice), Prof. Marie-Claire Cordonier Segger (Director, CISDL), Prof. Hans von Sponeck (former UN Under-Secretary), Dr. Scilla Elworthy (founder, Oxford Research Group), Dr. Rama Mani (UN advisor, Responsibility 2 Protect), Prof. Hans Peter Dürr (Nuclear Physist), Dr. David Krieger (founder, Nuclear Age Peace Foundation), Prof. Stephen Marglin (Harvard Economist), Dr. Katiana Orluc (expert, Middle East), Sulak Sivaraksa (founder, Network of Engaged Buddhists), Dr. Vithal Rajan Vice-President, Oxfam India, Chairman, Governing Body/Confederation of Voluntary Associations, Hafsat Abiola Founder, Kudirat Initiative for Democracy (KIND), Frances Moore-Lappé (founder, Small Planet Institute), Jakob von Uexküll (founder, Right Livelihood Award). For an overview of the Commission's different projects see http://www.worldfuturecouncil.org/futurejustice.html.

3. The following section is taken from the original legal research paper World Future Council/Centre for International Sustainable Development Law "Selecting Best Law for Future Generations" Legal Working Paper and Worked Examples; Cordonier Segger, M.C., Rana, R., Eds.; World Future Council (WFC): Hamburg, Germany, 2008; pp. 7-10; Available online: http://www.worldfuturecouncil.org/future_justice_principles.html (accessed on 6 January 2010).

4. Cordonier Segger, M.C. Significant Developments in Sustainable Development Law and Governance: A Proposal. Nat. Resour. Forum 2004, 28, 61-74.

5. International Law and Sustainable Development since Rio-Legal Trends in Agriculture and Natural Resource Management; Food and Agriculture Organization (FAO): Rome, Italy, 2002.

6. Cordonier Segger, M.C.; Khalfan, A.; Gehring M.; Toering, M. Prospects for Principles of International Sustainable Development Law after the WSSD: Common but Differentiated Responsibilities, Precaution and Participation. Rev. Eur. Commun. Int. Environ. Law 2003, 12, 54-68.

7. Stockholm Declaration of the UN Conference on the Human Environment, Stockholm, Sweden, 5-16 June 1972; UN Doc A/Conf 48/14/Rev.1, 11 ILM 1461.

8. Our Common Future; Report of the UN World Commission on Environment and Development; UN: New York, NY, USA, 4 August 1987; UN Doc A/42/427; Available online: http://www.undocuments.net/ocf-10.htm (accessed on 7 January 2010).

9. Rio Declaration on Environment and Development (Annex 2); Report of the UN Conference on Environment and Development; UN: New York, NY, USA, 13 June 1992; Volume I, Doc A/CONF.151/26 31 ILM 874.

10. Agenda 21 (Annex 2); Report of the UN Conference on Environment and Development; UN: New York, NY, USA, 13 June 1992; Volume I, Doc A/CONF.151/26.

11. Boyle, A. Soft Law in International Law-Making. In International Law, 2nd ed.; Evans, M., Ed.; Oxford University Press: Oxford, UK, 2006; p. 142.

12. Cordonier Segger, M.C.; Khalfan, A. Sustainable Development Law: Principles, Practices and Prospects; Oxford University Press: Oxford, UK, 2005.

13. French, D. International Law and Policy of Sustainable Development; Manchester University Press: Manchester, UK, 2005. 
14. Report of the Expert Group Meeting on Identification of Principles of International Law for Sustainable Development; Division for Sustainable Development: Geneva, Switzerland, 26-28 September 1995.

15. Background Paper for the UNCSD; UNCSD: New York, NY, USA, 18 April-3 May 1996; Available online: http://www.un.org/documents/ecosoc/cn17/1996/background/ecn171996bp3.htm (accessed on 12 December 2009).

16. See, ILA New Delhi Declaration of Principles of International Law Relating to Sustainable Development. Int. Environ. Agreem.: Politic., Law Econ. 2002, 2, 209-216.

17. Schrijver, N.; Weiss F. Editorial Introduction. Int. Environ. Agreem.: Politic., Law Econ. 2002, 2, 105-108; see also Report of the Expert Group on Identification of Principles of International Law for Sustainable Development; International Law Association (ILA): London, UK, 1995; Report of the Sixty-Second Conference; International Law Association (ILA): Seoul, Korea, 1987; pp. 1-11, 409-487.

18. Official Documents from the World Summit for Sustainable Development; WSSD Documents; World Summit for Sustainable Development (WSSD): Mumbai, Maharashtra, India, August 2002; Available online: http://www.un.org/jsummit/html/documents/summit_docs.html (accessed on 7 January 2010); see also Johannesburg Declaration on Sustainable Development and Johannesburg Plan of Implementation; Report of the World Summit on Sustainable Development; UN: New York, NY, USA, 4 September 2002; Doc A/CONF.199/L20.

19. Schrijver, N.; Weiss, F. International Law and Sustainable Development: Principles and Practice; Martinus Nijhoff: Leiden, The Netherlands, 2004; pp. 1-152, 699-706.

20. For a discussion of the Declaration by the Chair of the ILA Committee see Shrijver, N. The New Delhi Declaration: Principles of International Law Related to Sustainable Development. In Sustainable Justice. Reconciling Economic, Social and Environmental Law; Martinus Nijhoff Publishers: Leiden, The Netherlands, 2005; pp. 549-560.

21. Johannesburg Plan of Implementation; UN: New York, NY, USA, 2002; Doc. A/CONF.199/20.

22. An introduction to the commission's agreed goals and a list of its members are available online: http://www.worldfuturecouncil.org/futurejustice_commission.html (accessed on 7 January 2010).

23. Human Security Now, Commission on Human Security; United Nations Publications: New York, NY, USA, 2003; p. 4. The definition continues as follows: "Human security means protecting fundamental freedoms - freedoms that are the essence of life. It means protecting people from critical (severe) and pervasive (widespread) threats and situations. It means using processes that build on people's strengths and aspirations. It means creating political, social, environmental, economic, military and cultural systems that together give people the building blocks of survival, livelihood and dignity" (ibid).

24. United Nations Millennium Development Goals; Available online: www.un.org/millenniumgoals (accessed on 8 January 2010).

25. Universal Declaration of Human Rights; UN: New York, NY, USA, 1948; Available online: http://www.un.org/en/documents/udhr/ (accessed on 15 November 2009).

26. International Covenant on Economic, Social and Cultural Rights; 1966, Art. 11; Available online: http://www2.ohchr.org/english/law/cescr.htm (accessed on 21 January 2010). 
27. Declaration of the World Summit in Food Security; 2009, footnote p. 1; Available online: http://www.fao.org/fileadmin/templates/wsfs/Summit/Docs/Final_Declaration/WSFS09_Declarati on.pdf (accessed on 10 December 2009).

28. The Declaration is available online: http://www.fao.org/fileadmin/templates/wsfs/Summit/CSO_ docs/Final_Declaration-EN.pdf (accessed on 10 December 2009).

29. Food Security; Policy Brief; Food and Agriculture Organization (FAO): Rome, Italy, February 2006; Available online: ftp://ftp.fao.org/es/ESA/policybriefs/pb_02.pdf (accessed on 9 January 2010).

30. The actual legal text is available online in Italian: http://germoplasma.arsia.toscana.it/ Germo_old/PN_GERMO/Download/testoBURT.pdf; there also exists an unofficial translation into English; Available online: http://www.gmo-freeregions.org/Downloads/WS_B5_TUSC ANY\%20LAW\%20ON\%20SEEDS.pdf (accessed on 29 July 2009).

31. An official and extensive, yet descriptive review of all elements of the reform of the agricultural sector in 1993 by the Cuban government is available online in Spanish: http://reformagraria.cip.cu/actualidad/Sit_actual_de_la_agricultura.html (accessed on 8 January 2010).

32. The actual legal text is available online in Portuguese, including a list of amendments over the years: http://cmbhapweb.cmbh.mg.gov.br:8080/silinternet/consultaNormas/detalheNorma.do?id $=2 \mathrm{c} 907 \mathrm{f} 7617 \mathrm{f} 883 \mathrm{~d} 00117 \mathrm{f} 89 \mathrm{a} 96 \mathrm{~d} 9000 \mathrm{f} \&$ metodo=detalhar (accessed on 28 July 2009); the 2008 text turning the program into one concise law is available online in Portuguese: http://www.jusbrasil.com.br/legislacao/236031/lei-9527-08-belo-horizonte-mg; (accessed on 4 February 2010); the national law on food security formulated in 2006 with similar characteristics is available online in English: http://www.google.com/url?sa=t\&source=web\&ct=res\&cd= $1 \&$ ved=0CAcQFjAA\&url=http $\% 3 \mathrm{~A} \% 2 \mathrm{~F} \% 2 \mathrm{Fwww}$.planalto.gov.br\%2Fconsea $\% 2 \mathrm{~F} 3$ conferencia $\%$ 2Fstatic\%2FDocumentos\%2FLosan_Ing1\%25EAs.pdf\&ei=dfpFS7ekCt_9sQb6vui5Aw\&usg=AF QjCNGQtJFXUhpP_2Urg5Cjy1H6wCeigQ\&sig2=VKQIZY3ghEeztrsDIoj6QQ (accessed on 11 January 2010).

33. Detailed information about the strategy and the program details are available online: http://www.mfa.gov.et/Miscellanies/FoodSecurity.php?Page=FoodSecurity/TOC.htm (accessed on 11 January 2010).

34. A document outlining the entire vision, strategy and implementation measures of Kerala State Organic Farming Policy is available online: http://www.keralabiodiversity.org/pdf/policy.pdf (accessed on 6 December 2009).

35. It is of course necessary to consider external conditions within which a policy can become effective: if continued draughts ruin the national harvest, this translates into a fundamentally different challenge than distributing available food more justly. The Ethiopian policy, however, also had shortcomings in the design of some of its mechanisms so that even the interviewees themselves judged it to not qualify for a "best policy" yet.

36. See Interview Transcript of the Film Silent Killer, 2005; Available online: http://www. silentkillerfilm.org/interview_aranha.html (accessed on 8 December 2009). 
37. Food and Agriculture Statistics Global Outlook; Statistics Division, UNFAO: Rome, Italy, June 2006; p. 1; Available online: http://faostat.fao.org/Portals/_Faostat/documents/pdf/world.pdf (accessed on 21 September 2009).

38. The State of Food Insecurity in the World 2006; UNFAO: Rome, Italy, 2006; pp. 32-33; Available online: http://www.fao.org/docrep/009/a0750e/a0750e00.htm (accessed on 7 December 2010).

39. Human Development Report 2005; World Bank: Washington, DC, USA, 2005; p. 30.

40. Policy Brief No. 2; UNCTAD: Geneva, Switzerland, June 2008; p. 1; Available online: http://www.unctad.org/Templates/Download.asp?docid=10111\&lang=1\&intItemID=4566 (accessed on 15 September 2009).

41. Life Cycle-Based Sustainability Indicators for Assessment of the US Food System; The Center for Sustainable Systems: Ann Arbor, MI, USA, 2000; p. 30; Available online: http://css.snre.umich. edu/css_doc/CSS00-04.pdf (accessed on 15 September 2009).

\section{Appendix}

Introducing a Principled Questionnaire for Policy Assessment

This Appendix provides the details on the research methodology adopted. It includes Future Justice questionnaire for policy review, which lists each of the seven principles, as well as objective, interrelated questions about adherence to these principles to guide the experts' assessment. This questionnaire was followed strictly in a standardized research process and the answers were documented in a template to ensure comparability. The questionnaire is reproduced below and the research process explained before the template descriptions of key features of the laws under scrutiny is provided [39]. This Appendix also includes the research standard and methodology used to evaluate the results from this questionnaire.

\section{Questionnaire to Operationalize the ILA Sustainable Development Principles}

1. The duty to ensure sustainable use of natural resources

Law and policy-makers, by virtue of their role as stewards of natural resources, have a duty to ensure that these resources are used in a way that is economically, socially and environmentally sustainable so that they can be replenished over the long term. This principle focuses, in an integrated manner, on the environmental and socio-economic durability of the law/policy.

1.1. Does the law/policy help to ensure that the Earth's scarce resources will be used in a more sustainable way?

1.2. Does it help to address a common concern of humankind (such as climate change, global extinction of species, collapse of world fish stocks)?

1.3. Does it respect natural areas, artifacts and traditional knowledge, all of which are the common heritage of humankind? 
2. The principle of equity and the eradication of poverty

Laws and policies can contribute to equity and poverty eradication, or make conditions more unequal for the peoples affected by the measure. They can also affect the ability of future generations to fulfill their needs. This principle focuses on the law/policies impact on society, recognizing that often, social conditions are already vastly unequal and ensures that a law/policy can improve quality of life for the peoples affected.

2.1. Does the law/policy help to address pressing poverty and human rights challenges?

2.2. Does it demonstrate respect among generations, by including provisions that take into account the needs and aspirations of future generations of life?

2.3. Does it promote respect within the present generation of life, by promoting social justice, equity for all peoples, an end to gender discrimination, respect for the rights of indigenous peoples and local communities, eradication of poverty and less discrimination among species?

3. The principle of the precautionary approach to human health, natural resources and ecosystems

Laws and policies can place ecosystems and societies at risk, and make it possible for societies to address these risks. Often, a new law or policy is enacted as part of a community's broader set of rules for risk management such as impact assessment laws and policies, rather than including specific provisions within the law/policy itself, and this must be taken into account by evaluators. This principle focuses on whether the law/policy helps to ensure that where science is not certain, risks are wisely and equitably managed.

3.1. Does the law/policy promote prevention and precaution in the face of scientific uncertainty about a threat of serious or irreversible harm?

3.2. Does it place the burden of proof for demonstrating that a project or activity is safe, or that risks are reasonable, on the proponent of the venture?

3.3. Where there is insufficient scientific evidence, does it ensure that those most affected by a project can set the acceptable level of risk or threat?

4. The principle of public participation and access to information and justice

Laws and policies benefit from a drafting process that is transparent and participatory, but this principle focuses on how the policy ensures that it is implemented in a way that is transparent and inclusive. Many new laws or policies are contingent on broader existing transparency, public participation measures such as access to information, consumer labeling schemes, or public engagement programming, and this must be taken into account by evaluators.

4.1. Does the law/policy provide for public consultation and genuine engagement, in both its provisions and implementation?

4.2. Does it specifically provide for transparency and access to information for concerned citizens, local communities, and others who might be affected?

4.3. Does it provide avenues for appeal and redress for citizens, communities and others? 
5. The principle of governance and human security

Laws and policies can contribute to good governance and human security, or detract from them. This principle focuses on whether the law includes, within its provisions, ways to ensure that people cannot take advantage of its provisions. It also focuses the evaluator's attention on existing legal or social norms that prevent all laws from being mis-applied, such as monitoring and assessment of institutions, anti-bribery and corruption rules, as these mechanisms may be the key to securing fair and just implementation of the law/policy.

5.1. Does the law/policy establish adequate institutions to ensure transparent, prompt, effective and fair implementation of its provisions?

5.2. Does it promote peaceful resolution of conflict, and help to ensure that human beings are able to live in freedom from fear, and freedom from want?

5.3. Does the law/policy include provisions to ensure that its intentions are not thwarted by corruption, bribery or unethical conduct, and provide appropriate penalties for abuse of rights, or for mis-implementation?

6. The principle of integration and interrelationship, in particular in relation to human rights and social, economic and environmental objectives

Laws and policies can contribute to fragmentation and territoriality between the very institutions that are meant to work together for sustainability, or they can encourage cooperation and integration. They can include specific mechanisms to make jurisdictions clear, promote institutional learning, and facilitate good inter-agency cooperation. Societies might also have other rules to do this, such as impact assessment, inter-agency consultation or cost internalization rules, which form part of the context of the law/policy and need to be taken into account in its evaluation. This principle focuses on how the law/policy encourages integrated decision-making about sustainable development.

6.1. Does the law/policy integrate social justice and environmental protection into economic development plans and projects?

6.2. Does it ensure that development decision-making takes environmental and social impacts into account, providing for mitigation, modification or cancellation if necessary?

6.3. Does it provide or enhance benefits for the environment and society?

7. The principle of common but differentiated obligations

Laws and policies might address only a present problem, or they can take into account past inequalities, differing conditions and unequal capacities which affect the way obligations can be met. This principle focuses specifically on whether the law/policy could be appropriate for all societies or only in certain technological, scientific and cultural context, and whether the law/policy finds ways to ensure burdens and costs of implementation do not fall upon those least able to carry them. 
7.1 Does the law/policy take into account historical and other inequalities, including who has benefited from past activities and policies, when imposing obligations, and provide avenues to redress such inequalities where possible?

7.2 Is the law/policy appropriate and well adapted to the society or region's present level of technology, scientific knowledge, human/financial resources, cultural values and traditions?

7.3 Does it avoid placing inappropriate burdens on vulnerable groups, or imposing costs on those least equipped to bear them?

These "principled questions" are not exhaustive [39], nor will all questions apply to every law or policy. In essence, this standard seeks to answer the following fundamental question: What are the actions, practices and policies whose adoption could radically enhance the prospects of sustainability of life on our planet, to promote the integrity of future generations? Thus, if, on balance of considerations, a policy or law can be said to meet most of these principles where they are relevant, it could be held up as a universal or regional "best policy" that deserves wide replication.

\section{Defining a Legitimate Research Standard}

To apply the principled evaluation and to ensure comparability between the laws, the research process followed a five-step process:

1. Clearly identify the law or policy in all of its components (see references to legal texts above);

2. Scope key features of the policy for analysis and summarize in an overview (as presented above);

3. Select three knowledgeable and legitimate experts to evaluate the law or policy in a structured interview;

4. Apply the principled questionnaire cited above to the policy through archival research and interviews;

5. Prepare the evaluation report along the questionnaire and identify commonalities of the most successful laws (see one example report on Belo Horizonte in the Appendix).

In this methodology, the experts of course play a very central role in the process of applying the principles and for the quality of the evaluation. The selection should aim to guarantee that experts are able to provide an independent, knowledgeable and legitimate opinion and to represent different perspectives. In this case one policy maker, one civil society representative and one academic expert were chosen:

1. Policy maker experts representing the perspective of the government or organization in charge of creating and/or applying the law/policy gain their legitimacy from their knowledge of the origins and intentions of the law/policy, and their experience in its design and application.

2. Civil society experts knowledgeable about the impact of the policy on the affected community and its citizen gain their legitimacy from the respect accorded to them by their community, their reputation as a community leader, and their understanding of the needs of their community and how the policy meets these needs. 
3. Academic experts, who are ideally independent and knowledgeable about the technical aspects of the law/policy, should be able to provide a perspective on the comparative advantages and/or disadvantages of the law/policy with other similar laws/policies. Their legitimacy derives from established academic criteria such as expertise, reputation, peer-reviewed publications and recognition by scientific/legal peers in the field.

Thus, the evaluation is fundamentally based on values and qualitative, rather than quantitative data. The interviewed experts are being asked to give a subjective view on whether and how the law or policy addresses the core principles for sustainable development. The interviewer may have to add questions beyond the scope of the law/policy in question (for example about other laws or regulations connected to the law or policy under consideration). For instance, if a law or policy does not contain explicit impact assessment, anti-corruption, or public participation provisions because it is well-known that the society/government in question already has functioning laws on these issues which "complement" the law/policy and are applicable, the interviewed expert must be encouraged to speak of this context. There may also be a need to verify whether or not the law or policy has been affected by new laws, or whether the law or policy has recently been modified or updated. This was the case in three out of the five cases; participatory and regular evaluation and amendment actually proved to be one important characteristic that all "best policies" shared. Thus, it has proven necessary to undertake additional research and analysis on issues that the three interviewed experts were unable to address confidently.

(C) 2010 by the authors; licensee MDPI, Basel, Switzerland. This article is an Open Access article distributed under the terms and conditions of the Creative Commons Attribution license (http://creativecommons.org/licenses/by/3.0/). 